\title{
Metakaolin as an Active Pozzolan for Cement That Improves Its Properties and Reduces Its Pollution Hazard
}

\author{
Suzan S. Ibrahim 1*, Ayman A. Hagrass' ${ }^{2}$, Tawfik R. Boulos ${ }^{1}$, Samir I. Youssef', \\ Fouad I. El-Hossiny ${ }^{3}$, Mohamed R. Moharam4 \\ ${ }^{1}$ Central Metallurgical Research and Development Institute, Cairo, Egypt \\ ${ }^{2}$ El-Tabbin Institute for Metallurgical Studies, Cairo, Egypt \\ ${ }^{3}$ Faculty of Science, Ain Shams University, Cairo, Egypt \\ ${ }^{4}$ Faculty of Engineering, Azhar University, Cairo, Egypt \\ Email: *suzansibrahim@gmail.com, trboulos@gmail.com, Moreda_45@yahoo.com, Samiryoussefa@yahoo.com, \\ aahagrass@gmail.com, Fouadelhossiny@gmail.com
}

How to cite this paper: Ibrahim, S.S., Hagrass, A.A., Boulos, T.R., Youssef, S.I., El-Hossiny, F.I. and Moharam, M.R. (2018) Metakaolin as an Active Pozzolan for Cement That Improves Its Properties and Reduces Its Pollution Hazard. Journal of Minerals and Materials Characterization and Engineering, 6, 86-104.

https://doi.org/10.4236/jmmce.2018.61008

Received: December 29, 2017

Accepted: January 27, 2018

Published: January 30, 2018

Copyright $\odot 2018$ by authors and Scientific Research Publishing Inc. This work is licensed under the Creative Commons Attribution International License (CC BY 4.0).

http://creativecommons.org/licenses/by/4.0/

Open Access

\begin{abstract}
Prepared metakaolin produced by calcination of a kaolin sample at $750^{\circ} \mathrm{C}$ after soaking for $5 \mathrm{hrs}$ was tested as an active pozzolan for locally produced cement. Blended pastes of partially replaced ordinary Portland cement with different metakaolin amounts 5\%, 10\% and $15 \%$ were prepared, then they were hydrated with water for various time intervals of $1,3,7,14$ and 28 days. At each time interval, the hydrated paste specimens were tested for compressive strength, hydration kinetics and followed up using differential scanning calorimetry, X-ray diffractometry analyses and scanning electron microscopy techniques. Results showed that the blended pastes OPC-MK10 recorded the highest compressive strength values at all the hydration times reaching 33.10, $86.40,101.20,112$, and $122 \mathrm{MPa}$ with increasing the age of hydration as compared with the neat samples which recorded 31.70, 65.20, 72.6, 82 and 101.30 MPa respectively. Meanwhile, the OPC-MK10 blend showed a decrease in the free $\mathrm{CaO}$ content reaching $4.07 \%, 4.27 \%, 4.23 \%, 4.19 \%$, and $4.11 \% \mathrm{CaO}$ with increasing age of hydration compared with the neat samples which recorded $4.27 \%, 5.15 \%, 5.42 \%, 5.61 \%$, and $5.96 \% \mathrm{CaO}$ respectively. The DSC thermograms results for the hardened neat and OPC-Mk10 pastes at the 14 and 28 hydration days showed the formation of hydrated materials mainly calcium silicate hydrates, calcium sulphoaluminate hydrates and calcium aluminates hydrates. The X-ray diffractometry analyses of both hardened neat and OPCMK10 showed that, the intensity of calcium hydroxide peaks of OPC-MK10 was lower than in case of neat OPC, while the peak of the hydration products
\end{abstract}


of calcium silicate hydrates and calcium aluminates silicate hydrates of OPCMK10 samples were of higher intensity than in case of neat OPC. Scanning electron microscopy micrographs indicated the formation of denser microstructure for the hardened OPC-MK10 paste as compared to neat OPC pastes after the 28 days age of hydration.

\section{Keywords}

Metakaolin, Compressive Strengths, Hydration Kinetics

\section{Introduction}

Since the first Portland cement with the present definition was produced in 1843 by William Aspdin, there has been a continuous process of evolution in cement process technology and cement itself. Compared with other industries, the speed of development has been moderate, which can certainly be explained by the huge efforts needed to achieve safe and standardized concrete construction. Portland cement consists essentially of limestone mixed with a second material containing clay as source of alumino-silicate. Normally, an impure limestone which contains clay or silicon dioxide $\left(\mathrm{SiO}_{2}\right)$ is used. The calcium carbonate $\left(\mathrm{CaCO}_{3}\right)$ content of these limestones can be as low as $80 \%$. Indeed, with the manufacture of one ton of cement approximately 0.8 ton of $\mathrm{CO}_{2}$ is launched into the atmosphere, Table 1 . It accounts for approximately $8 \%$ of worldwide man-made $\mathrm{CO}_{2}$ emissions, [1]. Not only $\mathrm{CO}_{2}$ releases from cement manufacture but also $\mathrm{SO}_{3}$ and $\mathrm{NO}_{\mathrm{x}}$ which can cause the greenhouse effect and acid rain. These cause serious environmental impact, in addition to consuming considerable amounts of virgin materials (limestone and sand) and energy (energy demand about 1700 - 1800 $\mathrm{MJ} /$ ton clinker), producing each ton of PC of which about 1.5 ton of raw material is needed, [2].

The most effective way to reduce $\mathrm{CO}_{2}$ emission of cement production is to reduce the clinker content by blending cements with supplementary cementitious materials (SCMs), which are called pozzolans, [1]. Pozzolans materials could be classified into: natural pozzolan like volcanic glasses (volcanic ash), volcanic tuffs (zeolites, chlorites, feldspar, and quartz), and siliceous materials (diatomite, and ppt silica), or artificial pozzolans like burnt materials (burnt clay, burnt rice husk) or industrial by products (blast furnace slag, silica fume,

Table 1. Ordinary Portland Cement (OPC) Composition.

\begin{tabular}{cc}
\hline Component & $\mathrm{Wt} \%$ \\
\hline $\mathrm{SiO}_{2}$ & 21.30 \\
$\mathrm{CaO}$ & 63.20 \\
$\mathrm{Al}_{2} \mathrm{O}_{3}$ & 6.00 \\
$\mathrm{Fe}_{2} \mathrm{O}_{3}$ & 2.70
\end{tabular}


aluminum slag, copper slag). Generally they are mainly amorphous siliceous or siliceous and aluminous by-products after many industrial manufacturing processes, [3] [4] [5]. The most common of these are fly ash (FA), silica fume (SF), aluminous scraps, iron and steel industry slag, and metakaolin (MK). These materials are used to replace part of cement or as a source of new cementless materials and help in reducing the released free lime that is produced during clinker hydration, [6] [7]. By reducing calcium hydroxide, many negative features in the concrete will be eliminated. Among these, is the "Efflorescence" and the "decorative glass embedment" or "ASR". When calcium hydroxide reacts with carbon dioxide in the atmosphere, a whitish haze appears on concrete, called "Efflorescence". Because metakaolin consumes calcium hydroxide, it reduces efflorescence.

ASR can be explained as the situation where cement alkalis react with certain forms of silica in the aggregate component of a concrete, forming an alkali-silica gel at the aggregates surface. This formation often referred to as "reaction rim" has a very strong affinity for water, and thus has a tendency to swell. These expanding compounds can cause internal pressures sufficiently strong to cause cracking of the paste matrix, which can then result in a compromised concrete with an open door to an increasing rate of deterioration. Due to the very fine and highly reactive nature of metakaolin, it gives fresh concrete a creamy, nonsticky texture that makes finishing easier, [6] [7].

Increased attention to the environmental impact of ordinary Portland cement (OPC) has prompted researchers to study the optimization of alternative clinker less construction materials. Due to the advantageous capabilities, the pozzolanic material is a prospective substitution to ordinary Portland cement, [8] [9] [10]. Various factors show that the pozzolanic activity of a certain material depends mostly on its chemical and mineralogical composition, and moreover, on the amorphous phase content, the dihydroxylation degree, the material's specific surface, and the water to binder ratio of the blended mixtures, [11].

The development of pozzolanic properties in fired clays mainly depends on the nature and abundance of clay minerals in the raw material, the calcination conditions and the fineness of the final product. The calcination temperature producing the reactive state is usually in the range of $600^{\circ} \mathrm{C}-800^{\circ} \mathrm{C}$. On heating, recrystallization and formation of metakaolin $\left(2 \mathrm{SiO}_{2} \cdot \mathrm{Al}_{2} \mathrm{O}_{3}\right)$ or mullite $\left(3 \mathrm{Al}_{2} \mathrm{O}_{3} \cdot 2 \mathrm{SiO}_{2}\right)$ takes place, resulting in a decline of material reactivity, [12]-[20]. It was reported that metakaolin $(\mathrm{MK})$ is highly reactive metastable clay that is essentially an anhydrous aluminosilicate obtained from calcining kaolin at around $650^{\circ} \mathrm{C}$ $700^{\circ} \mathrm{C}$. The reactivity of metakaolin varies with thermal treatment, [28] [29] [30] during calcinations $\left(450^{\circ} \mathrm{C}-600^{\circ} \mathrm{C}\right)$ and turns into metakaolin, a material with some degree of order. In metakaolin, the Si-O network remains largely intact while the structure of Al-O network is reorganized. After all, metakaolin offers good properties as supplementary cementing material. It results to high performance, high strength and high weight concrete to be employed in structural and non-structural components of bridges or in pavement overlays. It can also be 
used in precast and repetitive concrete products, e.g. cast stone, block, brick and paving stones. Similarly it can be employed in fiber cement, ferrocement and glass fiber reinforced concrete production. Evidently, the possolanic influence of MK will, at least, lead to the control of efflorescence and degradations caused by alkali silica reaction in concrete, [21]-[34].

MK typically contains $50 \%-55 \% \mathrm{SiO}_{2}$ and $40 \%-45 \% \mathrm{Al}_{2} \mathrm{O}_{3}$. Other oxides present in small amounts include $\mathrm{Fe}_{2} \mathrm{O}_{3}, \mathrm{TiO}_{2}, \mathrm{CaO}$, and $\mathrm{MgO}$. MK particles are generally one-half to five microns in diameter, an order of magnitude smaller than cement grains and an order of magnitude larger than silica fume particles. MK is white in color, making it particularly attractive in color matching and other architectural applications. Due to the controlled nature of the processing, MK powders are very consistent in appearance and performance.

In this study, a thorough discussion of the role of metakaolin on locally produced cement performance in view of the formation of cementitious materials will be carried out in a "Step on the Road" for a better understanding of its possolanic activity.

\section{Experimental Techniques}

\subsection{Materials}

A technological kaolin ore sample was collected as lumps from El-Teeh deposit, northeast of Abu Zenima locality, Sinai Peninsula, Egypt. The Ordinary Portland cement (OPC) CEM I, $52.5 \mathrm{R}$ was provided by EL-Arish Cement Company, Egypt.

The kaolin ore head sample was pulverized using Denver jaw crusher to reach $100 \%$ below $11.20 \mathrm{~mm}$. The crushed product was then directed to stirring attrition wet grinding using the laboratory "Union Process Attritor" model 1S to reach $100 \%$ below 74 micron. The optimum milling conditions were $6 \%$ by wt. solid pulp density, $67 \%$ by wt. grinding balls, $30 \mathrm{~min}$ attrition time at $458 \mathrm{rpm}$ stirring speed, [35]. The ground product was then directed to 74 micron sieve classification to reject the over screen silica rich product, where the under screen product was further classified through 3" and 1" Mozley hydro-cyclones. The final 1" hydro-cyclone over flow product was collected, dried, and evaluated as the kaolin concentrate, [35]. The calcination tests of the kaolin concentrate product were carried out in programmable furnace, with a heating rate from a room temperature to the appointed temperature of $20^{\circ} \mathrm{C} / \mathrm{min}$.

\subsection{Hardened Cement Pastes, Preparation and Measures}

Series of mixtures were prepared from ordinary Portland cement (OPC) blended with different amounts of metakaolin as $5 \%, 10 \%$, and $15 \%$ by wt. Each dry mixture was mechanically stirred for 3 hours in porcelain mixer to attain complete homogeneity then kept in air-tight containers for further investigation. The water requirements of the cementitious mixtures (Normal consistency) as well as initial and final setting times were measured by Vicat apparatus according to 
ASTM C 187, 191, [36]. Each dry mixture was mixed with the determined amount of water for about 3 minutes. After mixing, the resulting pastes were molded into cubic specimens $(2.54 \mathrm{~cm} \times 2.54 \mathrm{~cm} \times 2.54 \mathrm{~cm})$ by using stainless steel cubic moulds. Immediately after molding, the moulds were cured at about $100 \%$ relative humidity at room temperature for 24 hours in order to attain the final setting of the specimens, [37]. The hardened cement pastes were then removed from the moulds and cured under tap water. The applied time intervals were 3, 7, 14 and 28 days of hydration. The stopping of hydration process was performed on the crushed cubic specimens after the compressive strength determination. The stopping solution was composed of methyl alcohol and acetone (1:1 by volume), [38]. Finally the powdered samples were dried at $80^{\circ} \mathrm{C}$ for three hours in $\mathrm{CO}_{2}$-free atmosphere and maintained in a desiccator for further investigation. Kinetics of the hydration process was studied from the determination of chemically-combined water $(\mathrm{Cw}, \%)$ and free lime $(\mathrm{CaO}, \%)$ contents for the hardened specimens at different intervals time of hydration, [39].

\subsection{Samples Characterization}

Thermal analysis (DTG and DSC) was carried out using "NETZSCH STA 409 C/CD". FRITSCH. Particle size analysis was measured by the Laser-ParticleSizer "analysette 22". Phase analysis of the samples was conducted by using XRD diffractometer, model" Bruker axs, D8 Advance. Scanning electron microscope (SEM) pictures were carried out using FEI Inspect S50 Scanning electron microscope.

\section{Results and Discussions}

\subsection{Metakaolin Preparation and Characterization}

Table 2 illustrates the major oxides contents of the kaolin head sample. The results showed that the sample was of moderate grade with respect to its alumina content $\left(27.78 \% \mathrm{Al}_{2} \mathrm{O}_{3}\right)$. It contained about $18 \%-20 \%$ free silica with minor amounts of dolomite, iron oxide, and titanium oxide reaching $4.46 \%, 2.43 \%$, and $1.51 \%$, respectively, Table 2 . The chemical analysis of kaolin concentrate product was depicted in Table 3. The sample was shown to be high grade with respect to its alumina content, $36.93 \% \mathrm{Al}_{2} \mathrm{O}_{3}$. It contained lesser amount of silica reaching about $6 \%$, and minor content of titanium and iron oxides reaching

Table 2. Chemical analysis of kaolin head sample.

\begin{tabular}{cccccccc}
\hline Constituent & $\mathrm{Al}_{2} \mathrm{O}_{3}$ & $\mathrm{SiO}_{2}$ & $\mathrm{TiO}_{2}$ & $\mathrm{Fe}_{2} \mathrm{O}_{3}$ & $\mathrm{MnO}$ & $\mathrm{CaO}+\mathrm{MgO}$ & LOI \\
\hline $\mathrm{Wt} \%$ & 27.78 & 52.25 & 1.51 & 2.43 & 0.88 & 4.43 & 10.99 \\
\hline
\end{tabular}

Table 3. Chemical analysis of kaolin concentrate.

\begin{tabular}{ccccccc}
\hline Constituent & $\mathrm{Al}_{2} \mathrm{O}_{3}$ & $\mathrm{SiO}_{2}$ & $\mathrm{Fe}_{2} \mathrm{O}_{3}$ & $\mathrm{TiO}_{2}$ & $\mathrm{CaO}+\mathrm{MgO}$ & LOI \\
\hline $\mathrm{Wt} \%$ & 34.49 & 49.92 & 0.57 & 0.38 & 1.87 & 12.77 \\
\hline
\end{tabular}


$0.38 \% \mathrm{TiO}_{2}$ and $0.57 \% \mathrm{Fe}_{2} \mathrm{O}_{3}$, Table 3. The laser particle size analysis of the sample depicted that the $\mathrm{D}_{50}$ and $\mathrm{D}_{90}$ of the product reached 2.85 and 10 micron, respectively.

The calcinations results of the processed kaolin showed the loss in wt.\% in the calcined samples after different firing temperatures and times, Table 4. It is clear that at temperature $750^{\circ} \mathrm{C}$ for $5 \mathrm{hrs}$, the de-hydroxylation of kaolin sample reached its optimum condition by a loss in the sample weight of about $11.20 \%$. The SEM micrograph pictures of the MK particles showed that they were one-half to five microns in diameter where the cement grains were about 10 micron in diameter, Figure 1. On the other hands, the chemical constitution of the produced metakaolin showed that it contained $55 \% \mathrm{SiO}_{2}$ and $41.14 \% \mathrm{Al}_{2} \mathrm{O}_{3}$, Table 5.

\subsection{Hardened Neat OPC and OPC-MK Pastes, Compressive Strength and Hydration Kinetics Measures}

The standard water consistency (W/C) was measured to be 27, 29, 31, and 33 for the neat and hardened cement pastes mixtures at $5 \%, 10 \%$, and $15 \% \mathrm{MK}$, respec-

Table 4. Loss in Wt\% after Calcination at Different Temperatures and Times.

\begin{tabular}{cccccccccc}
\hline Firing Time, hr & $500^{\circ} \mathrm{C}$ & $550^{\circ} \mathrm{C}$ & $600^{\circ} \mathrm{C}$ & $650^{\circ} \mathrm{C}$ & $700^{\circ} \mathrm{C}$ & $750^{\circ} \mathrm{C}$ & $800^{\circ} \mathrm{C}$ & $850^{\circ} \mathrm{C}$ & $900^{\circ} \mathrm{C}$ \\
\hline 1 & 5.42 & 9.44 & 10.31 & 10.63 & 10.85 & 11.14 & 11.04 & 11.05 & 11.05 \\
2 & 8.52 & 9.87 & 10.50 & 10.68 & 10.92 & 11.01 & 11.05 & 11.07 & 11.06 \\
3 & 8.68 & 10.11 & 10.53 & 10.76 & 10.98 & 11.12 & 11.05 & 11.10 & 11.07 \\
4 & 8.89 & 10.21 & 10.57 & 10.77 & 10.99 & 11.07 & 11.08 & 11.12 & 11.20 \\
5 & 9.46 & 10.28 & 10.61 & 10.83 & 11.05 & 11.20 & 11.08 & 11.12 & 11.20 \\
\hline
\end{tabular}

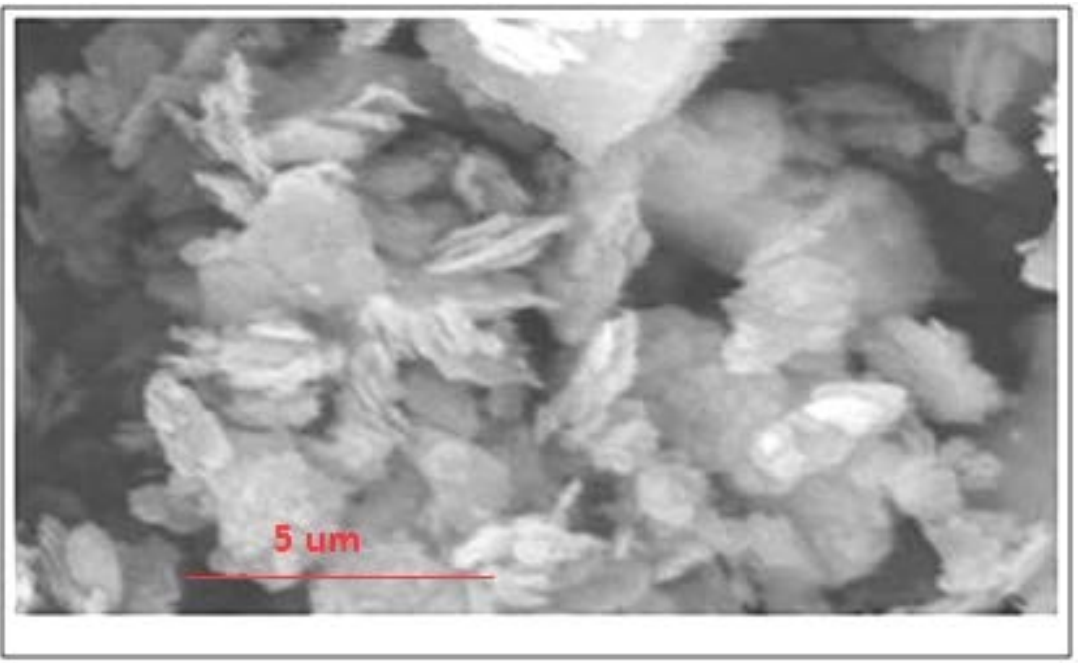

Figure 1. The SEM pictures of the produced metakaolin.

Table 5. Chemical analysis of the produced metakaolin.

\begin{tabular}{ccccc}
\hline Component & $\mathrm{Al}_{2} \mathrm{O}_{3}$ & $\mathrm{SiO}_{2}$ & $\mathrm{TiO}_{2}$ & $\mathrm{CaO}+\mathrm{MgO}$ \\
\hline$\%$ & 41.14 & 55.00 & 1.08 & 2.78 \\
\hline
\end{tabular}


tively, Figure 2. On the other hand, the initial and final setting times of theses pastes were shown to be $110,120,135$, and $140 \mathrm{~min}$ for initial setting times, and 180, 190, 195, and $205 \mathrm{~min}$ for the neat and blended pastes, respectively, Figure 3.

The results of the compressive strength, the non-evaporable (chemicallycombined water), and the free lime contents of the neat and blended pastes (MK5, MK10 and MK15) are given in Tables 6-9, respectively. The results showed that the compressive strength measures for the neat Portland cement pastes demonstrates a remarkable increase during the early ages of hydration up to 3 days from $31.70 \mathrm{MPa}$ at 1 day hydration to $65.20 \mathrm{MPa}$ at 3 days hydration, reaching an increase by $105.68 \%$. This was followed by gradual increase in the compressive strength up to the final age of hydration (28 days) reaching 72.60 , 82.00, and 101.30 Mpa by an increase amounted $11.35 \%, 12.95 \%$, and $23.54 \%$, respectively, Table 6 . The fast hydration during the early three days led to the formation of hydration products mainly as calcium silicate hydrates (C-S-H)

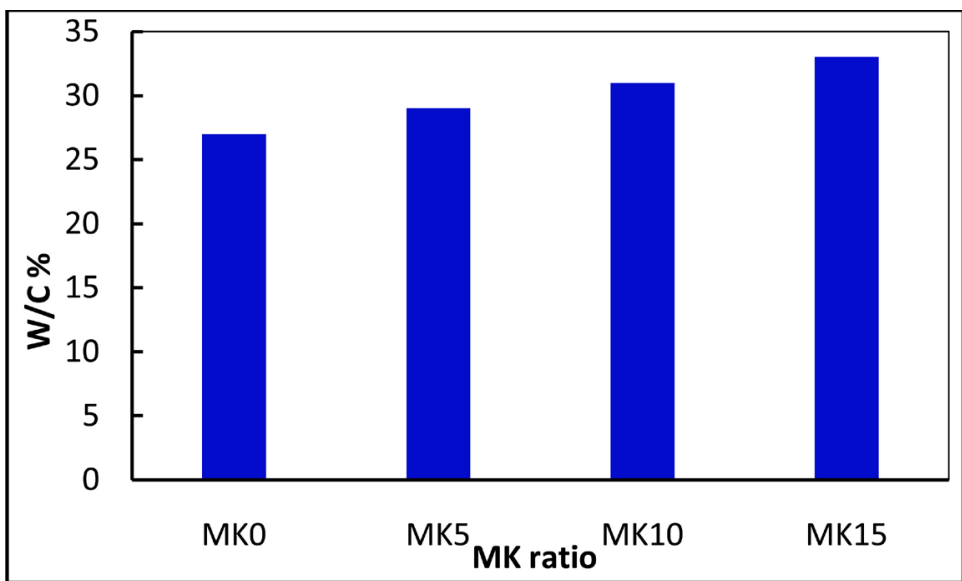

Figure 2. The standard water of consistency measures.

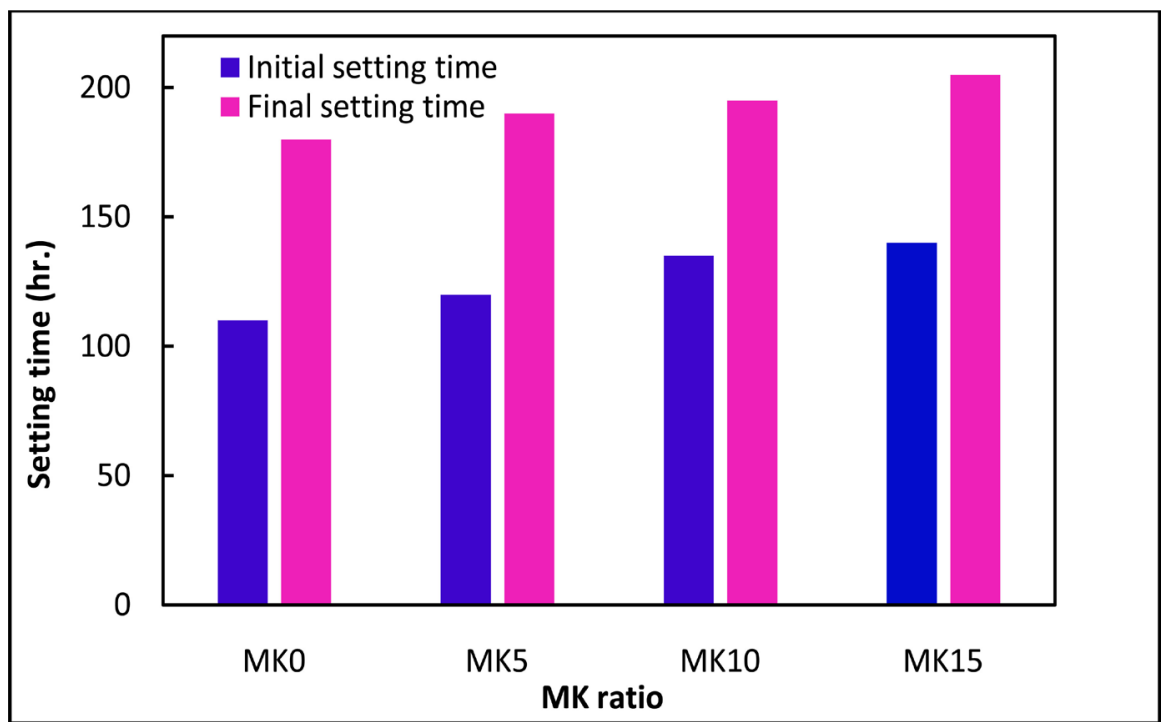

Figure 3. The Vicat initial and the final setting times at standard water of consistency. 
Table 6. Compressive strength and hydration kinetics of hardened neat OPC.

\begin{tabular}{cccc}
\hline Age of hydration (days) & $\begin{array}{c}\text { Compressive } \\
\text { strength (MPa) }\end{array}$ & $\begin{array}{c}\text { Combined water content } \\
(\mathrm{Cw}, \%)\end{array}$ & $\begin{array}{c}\text { Free lime content } \\
(\mathrm{CaO}, \%)\end{array}$ \\
\hline 1 & 31.70 & 7.80 & 4.27 \\
3 & 65.20 & 13.50 & 5.15 \\
7 & 72.60 & 16.10 & 5.42 \\
14 & 82.00 & 16.25 & 5.61 \\
28 & 101.30 & 16.48 & 5.96 \\
\hline
\end{tabular}

Table 7. Compressive strength and hydration kinetics of hardened OPC-MK5.

\begin{tabular}{cccc}
\hline Age of hydration (days) & $\begin{array}{c}\text { Compressive } \\
\text { strength (MPa) }\end{array}$ & $\begin{array}{c}\text { Combined water content } \\
(\mathrm{Cw}, \%)\end{array}$ & $\begin{array}{c}\text { Free lime content } \\
(\mathrm{CaO}, \%)\end{array}$ \\
\hline 1 & 32.00 & 9.94 & 4.19 \\
3 & 82.70 & 15.50 & 4.61 \\
7 & 98.40 & 16.70 & 4.96 \\
14 & 103.30 & 16.35 & 4.69 \\
28 & 116.00 & 16.78 & 4.65 \\
\hline
\end{tabular}

Table 8. Compressive strength and hydration kinetics of hardened OPC-MK10.

\begin{tabular}{cccc}
\hline Age of hydration (days) & $\begin{array}{c}\text { Compressive } \\
\text { strength (MPa) }\end{array}$ & $\begin{array}{c}\text { Combined water content } \\
(\mathrm{Cw}, \%)\end{array}$ & $\begin{array}{c}\text { Free lime content } \\
(\mathrm{CaO}, \%)\end{array}$ \\
\hline 1 & 33.10 & 10.65 & 4.07 \\
3 & 86.40 & 15.60 & 4.27 \\
7 & 101.20 & 16.40 & 4.23 \\
14 & 112.00 & 16.90 & 4.19 \\
28 & 122.00 & 16.79 & 4.11 \\
\hline
\end{tabular}

Table 9. Compressive strength and hydration kinetics of hardened OPC-MK15.

\begin{tabular}{cccc}
\hline Age of hydration (days) & $\begin{array}{c}\text { Compressive } \\
\text { strength (MPa) }\end{array}$ & $\begin{array}{c}\text { Combined water content } \\
(\mathrm{Cw}, \%)\end{array}$ & $\begin{array}{c}\text { Free lime content } \\
(\mathrm{CaO}, \%)\end{array}$ \\
\hline 1 & 31.80 & 11.50 & 4.15 \\
3 & 67.70 & 15.20 & 4.07 \\
7 & 76.10 & 16.63 & 4.00 \\
14 & 85.30 & 17.00 & 3.81 \\
28 & 105.00 & 16.92 & 3.50 \\
\hline
\end{tabular}

which had good hydraulic characteristics and acted as good binding centers between the cement grains which caused an appreciable improvement in the measured compressive strength amounted $105.68 \%$.

On the other hand, all the metakaolin blended pastes showed improvement in 
their compressive strength measures by increasing the age of hydration, with various levels, Tables 6-9. In case of OPC-MK5, the measured compressive strength recorded $32.00,82.70,98.40,103,30$, and $116.00 \mathrm{MPa}$ with improvement reaching $0.95 \%, 26.84 \%, 35.54 \%, 25.97 \%$, and $14.51 \%$ compared to the neat samples, with increasing the age of hydration, respectively. In case of OPCMK10, the measured compressive strength recorded 33.10, 86.40, 101.20, 112.00, and $122.00 \mathrm{MPa}$ with improvement reaching $4.42 \%, 8.73 \%, 39.39,36.58 \%$, and $20.00 \%$ compared to the neat samples, with increasing the age of hydration, respectively, Table 8. In case of OPC-MK15 blend, the measured compressive strength recorded $31.80,67.70,76.10,85.30$, and $105.00 \mathrm{MPa}$ with improvement reaching $0.32 \%, 3.83 \%, 4.82 \%, 4.02 \%$, and $3.65 \%$ compared to the neat samples, with increasing the age of hydration, respectively. These results indicated that all the metakaolin blended pastes showed improvement in their compressive strength measures compared to the neat samples, by increasing the age of hydration, with various levels. This increase in the compressive strength values were mainly attributed to the pozzolanic effect of the metakaolin in the cement blended pastes, which could be detailed as follows: when water was added to the OPC-MK mixture, free calcium hydroxide $(\mathrm{CH})$ is liberated and its concentration increased as a result of initial hydration of OPC. The silica and alumina contents in the metakaolin fraction went into the solution quickly and reacted with the calcium hydroxide to form secondary hydration products mainly as calcium silicate hydrate ( $\mathrm{CSH})$ together with the formation of calcium aluminates hydrates (C2ASH8, C4AH13, C3AH6) which were precipitated as soon as saturation was approached, according to the following equations, [6]:

$$
\begin{gathered}
\text { C3S/C2S(clinker) }+\mathrm{H}_{2} \mathrm{O} \rightarrow \text { Calcium Silicate Hydrates }(\mathrm{C}-\mathrm{S}-\mathrm{H})+\mathrm{Ca}(\mathrm{OH})_{2} \\
\mathrm{Ca}(\mathrm{OH})_{2}+\mathrm{Mk}\left(\mathrm{Al}_{2} \mathrm{O}_{3} \cdot 2 \mathrm{SiO}_{2}\right) \\
\rightarrow \mathrm{CSH}\left(2^{\mathrm{ry}} \text { hydration product }\right)+\mathrm{C}_{2} \mathrm{ASH}_{8}, \mathrm{C}_{4} \mathrm{AH}_{13}, \mathrm{C}_{3} \mathrm{AH}_{6}
\end{gathered}
$$

These secondary hydration products served as micro-fills which led to a reduction in the total porosity of the pastes and hence increasing in the total contents of binding centers in the specimens and consequently caused increase in their compressive strength values. Meanwhile, the results showed that the highest compressive strength values were observed in case of OPC-MK10. Among the different OPC-MK10 pastes, the 7 day hydration showed the compressive strength measure reaching $101.20 \mathrm{MPa}$ with an improvement reaching $39.39 \%$. This was followed by a gradual decrease in the compressive strength reaching $36.58 \%$, and $20.00 \%$ at the ages of hydration 14 days, and 28 days, respectively. This was explained after the transformation of some hydration products from the acicular crystal form (ettringite) to the hexagonal tabular crystal form (C4AH19, and C2AH8) at the final stages of hydration (28 days), which caused a sharp depletion in the compressive strength of the hydrated paste OPC-MK10, [40]. On the other hand, the lowest compressive strength measures were recorded in case of OPC-MK15. They showed almost the same values as the neat 
pasted at all the hydration ages. This behavior may be attributed to the relative high dilution of OPC content in the OPC-MK15 blend which had more hydraulic properties than that of the present MK, [41].

The results of the chemically combined water $(\mathrm{Cw})$ content values for the neat OPC and the blends containing different amounts of metakaolin versus the ages of hydrations indicated fast hydration reactions were occurred from the time of mixing up to 3 days of hydration; this was followed by an acceleration stage of hydration up to 7 days of hydration. At this stage the initially formed hydration products shielded the cement grains leading to a slower rate of hydration reaction; this was followed by a gradual increase in the rate of hydration up to the final stages of hydration (28 days).

At 1 day hydration, the $\mathrm{Cw}$ values were $6.80,9.94,10.65$, and 11.50 for the neat OPC and the OPC-MK blends, respectively, with increase reaching $46.18 \%$, $55.88 \%$, and $69.12 \%$ for the three blends $5 \%, 10 \%$, and $15 \% \mathrm{MK}$, respectively. This was followed by a considerable increase in the $(\mathrm{Cw})$ values up to the $7 \mathrm{hy}$ dration days. The $\mathrm{Cw}$ measures at the 3 hydration days were 13.50, 15.50, 15.60, and 15.20 with increase reaching $14.81 \%, 15.55 \%$, and $12.59 \%$, respectively. This was followed by relative decrease in the rate of the hydration reactions followed by a gradual increase again up to the final stage of hydration ( 28 days). The increase in the chemically combined water was an indicator for the consumption of calcium hydroxide after its reaction with the reactive metakaolin, i.e. the increasing in the chemically combined water was an indicator for the reactivity of metakaolin as pozzolan material especially through the early stages of the hydration ages.

The results of the produced free lime through different age's intervals of hydration for the neat and blended cement specimens (MK5 - MK15) showed that for all samples, the produced free lime $(\mathrm{CH})$ increased gradually with increasing age of hydration. However, by increasing the metakaolin content in the blends from $5 \%-15 \%$, an appreciable decrease in the produced lime was observed. In case of OPC-MK10, the free lime contents recorded 4.07\%, 4.27\%, 4.23\%, 4.19\%, and $4.11 \% \mathrm{CaO}$, with a decrease reaching $4.68 \%, 17.09 \%, 21.96 \%, 25.31 \%$, and $31.04 \%$ after $1,3,7,14$, and 28 days of hydration, respectively. In case of OPCMK15, the free lime contents recorded 4.15\%, 4.07\%, 4.00\%, 3.81\%, and 3.50\% $\mathrm{CaO}$, with a decrease reaching $2.81 \%, 20.97 \%, 26.20 \%, 32.08 \%$, and $41.27 \%$ after $1,3,7,14$, and 28 hydration days, respectively.

The measured free lime was a result of two opposite actions, the first action was its increase due to the hydration of the Portland cement, and the second action was its consumption due to the pozzolanic reaction of metakaolin. This may explain the remarkable decrease in the free lime by increasing the percentage of metakaolin in the blend, [42]. From the previous mentioned data in section 3.2. It could be concluded that the OPC-MK10 blend showed the best results with respect to the increase in the compressive strength and the decrease in the produced free lime values at hydration ages 14 and 28 days. The OPC-MK10 blend 
recorded increase reaching $36.58 \%$ and $20.43 \%$ in the compressive strength compared to the neat OPC at hydration ages of 14 and 28 days, respectively. Meanwhile it recorded decrease reaching $25.31 \%$ and $31.04 \%$ in the produced free lime compared to the neat OPC at hydration ages of 14 and 28 days, respectively. From the previous results it could be concluded that the hardened OPC-MK10 showed the highest compressive strength values and the lowest free lime contents throughout all the ages of hydration intervals, Table 10.

\subsection{The Thermal Analyses Measures}

The thermo-gravimetry (TG), differential scan calorimetry (DSC), and differential thermal analysis (DTA) thermo-grams of the hardened neat and the hardened OPC-MK10 after 1, 14 and 28 days of hydration showed that for the hardened neat sample, the three endothermic peaks which are shown between $60^{\circ} \mathrm{C}$ - $130^{\circ} \mathrm{C}$ in Figures 4-6 were due to the dehydration of the interlayer calcium silicate hydrates $(\mathrm{CSH})$, calcium aluminate hydrates $(\mathrm{CAH})$, and calcium sulphoaluminate hydrates (CSAH). In addition, the weak endothermic peak that appeared below $100^{\circ} \mathrm{C}$ was mainly attributed to the removal of free water. The intensity of these endothermic peaks showed gradual increasing with the increase of the hydration time due to the excessive formation of larger amounts of $\mathrm{CSH}$. This may be due to the latter crystallization of CSH with aging, [43] [44] [45] [46]. The gradual increase in the decomposition rate of calcium hydroxide $(\mathrm{CH})$ liberated from the hydration of OPC with increasing the aging time appeared as a big endothermic peak at $410^{\circ} \mathrm{C}-450^{\circ} \mathrm{C}$, Figures $4-6$. The endothermic reaction due to the decomposition of calcium carbonate was shown between $660^{\circ} \mathrm{C}-720^{\circ} \mathrm{C}$. However, the decrease in the intensity of this endothermic peak with increasing the hydration age could be attributed to the reaction of $\mathrm{CO}_{2}$ with $\mathrm{CaCO}_{3}$ to form $\mathrm{Ca}\left(\mathrm{HCO}_{3}\right)_{2}$. It may be attributed also to the increase in the degree of crystallinity of hydration products, which was considered as an indication for the degree of carbonation of the hardened pastes, [43].

For the hardened OPC-MK10 blend, the endothermic peaks between which are shown between $90^{\circ} \mathrm{C}-150^{\circ} \mathrm{C}$ was due to the decomposition of calcium silicate hydrates $(\mathrm{CSH})$ which was overlapped with calcium sulphoaluminate hydrates (mainly ettringite and mono sulphate hydrates). The intensity of these

Table 10. Compressive strength and hydration kinetics of Hardened Neat and OPC-MK10.

\begin{tabular}{|c|c|c|c|c|c|c|c|c|c|}
\hline \multirow{2}{*}{$\begin{array}{c}\text { Age of } \\
\text { hydration (days) }\end{array}$} & \multicolumn{3}{|c|}{ Compressive strength, (MPa) } & \multicolumn{3}{|c|}{ Combined water content, $(\mathrm{Cw}, \%)$} & \multicolumn{3}{|c|}{ Free lime content, $(\mathrm{CaO}, \%)$} \\
\hline & OPC & OPC-MK10 & Increase, $\%$ & OPC & OPC-MK10 & Increase, $\%$ & OPC & OPC-MK10 & Decrease, $\%$ \\
\hline 1 & 31.70 & 33.10 & 4.42 & 7.80 & 10.65 & 36.54 & 4.27 & 4.07 & 4.68 \\
\hline 3 & 65.20 & 86.40 & 32.52 & 13.50 & 15.60 & 15.55 & 5.15 & 4.27 & 17.09 \\
\hline 7 & 72.60 & 101.20 & 39.39 & 16.10 & 16.40 & 1.86 & 5.42 & 4.23 & 21.96 \\
\hline 14 & 82.00 & 112.00 & 36.59 & 16.25 & 16.56 & 1.90 & 5.61 & 4.19 & 25.31 \\
\hline 28 & 101.30 & 122.00 & 20.43 & 16.48 & 16.79 & 1.91 & 5.96 & 4.11 & 31.04 \\
\hline
\end{tabular}




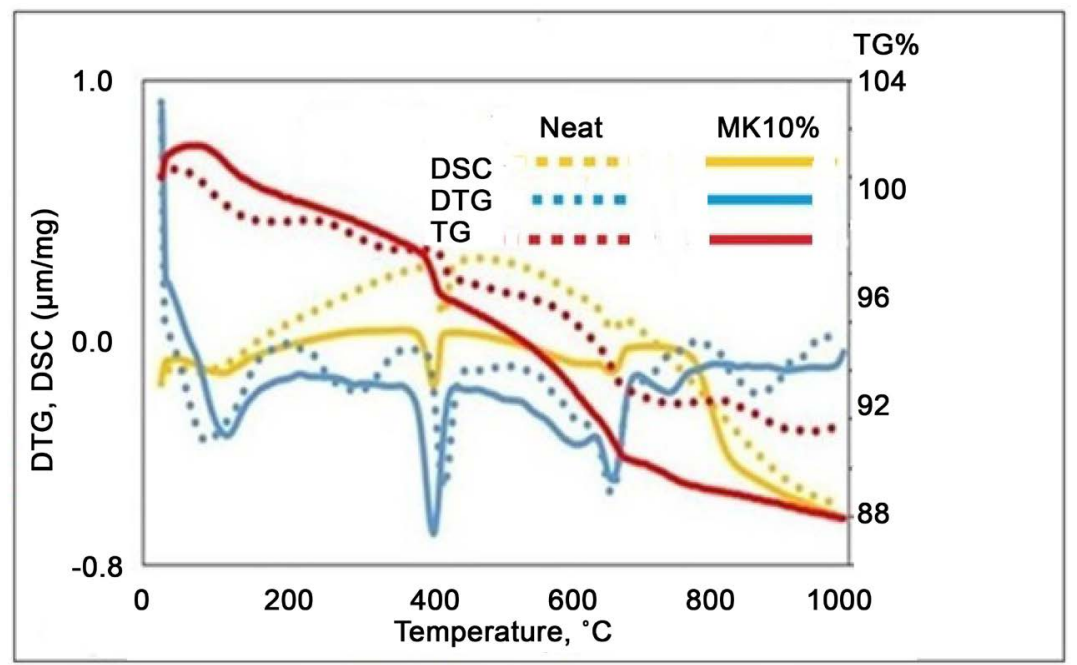

Figure 4. The Thermal analyses curves of the hardened neat OPC and OPC-MK10\% after 1 day.

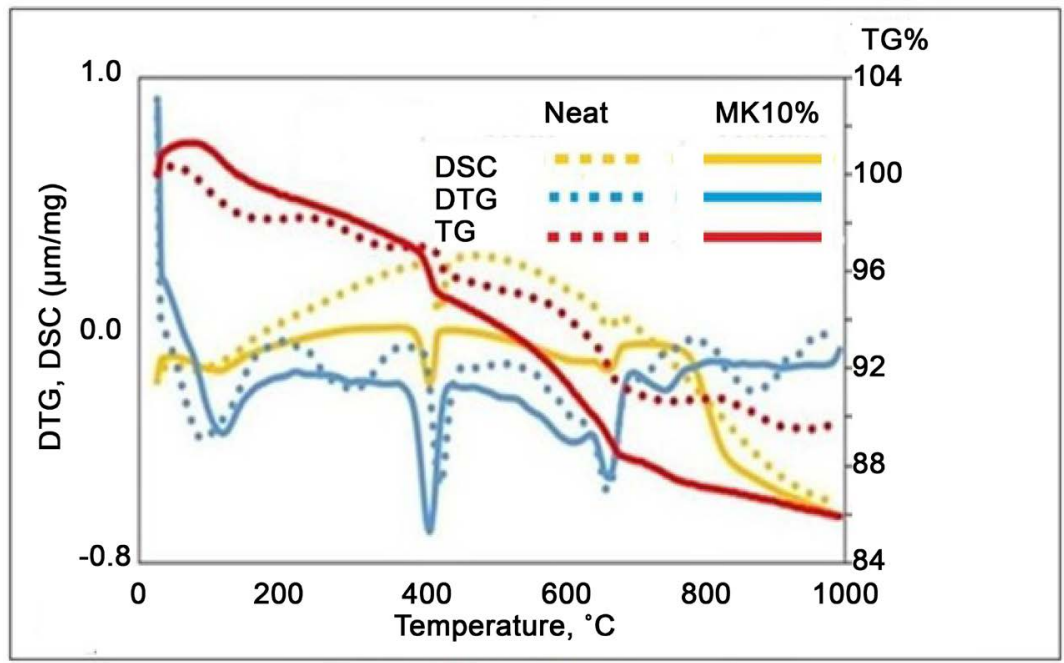

Figure 5. The Thermal analyses curves of the hardened neat OPC and OPC-MK10\% after 14 days.

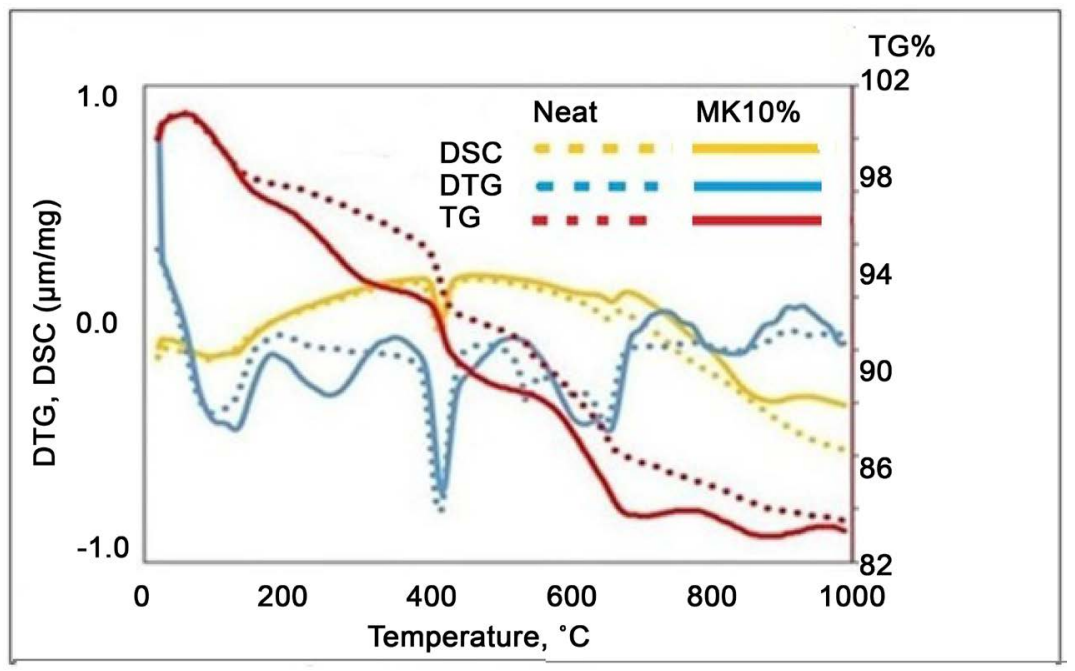

Figure 6. The Thermo-grams curves of hardened neat OPC and OPC-MK10\% after 28 days. 
endothermic peaks increased with the increase of hydration time due to the excessive formation of larger amounts of calcium silicate hydrates (CSH), as well as the pozzolanic reaction between the liberated $\mathrm{CH}$ and MK, [43] [44] [45] [46]. The endothermic peak at $400^{\circ} \mathrm{C}-440^{\circ} \mathrm{C}$ was representing the major loss in weight due to the decomposition of calcium hydroxide (portlandite). The intensity of this endothermic peak decreased with increasing age of hydration, Figures 4-6. These results were explained in terms of the decrease in the amount of free calcium hydroxide due to its pozzolanic consumption with MK. The endothermic peaks between $640^{\circ} \mathrm{C}-710^{\circ} \mathrm{C}$ were related to the decomposition of calcium carbonate with different degrees of crystallinity, [43] [44] [45] [46].

\subsection{Phase Analysis of Hardened Neat and OPC-MK10 after 28 Days Hydration}

The X-ray diffraction for the hardened cement pastes of the neat OPC and the OPC-MK10 blend after 28 days of hydration showed that the characterizing peaks of the tricalcium aluminates $\left(\mathrm{C}_{3} \mathrm{~A}\right)$ were not detected due to the fast rate of hydration and its reaction with gypsum that led to the formation of ettringite $\left(\mathrm{C}_{3} \mathrm{~A} \cdot 3 \mathrm{CaSO}_{4} \cdot 32 \mathrm{H}_{2} \mathrm{O}\right)$, Figure 7 . This mineral phase was transformed to the mono-sulphate hydrate $\left(\mathrm{C}_{3} \mathrm{~A} \cdot \mathrm{CaSO}_{4} \cdot 12 \mathrm{H}_{2} \mathrm{O}\right)$ during the early stages of hydration. These peaks were seemed to be overlapped with the peaks of unhydrated silicate and hydrated calcium silicates phases. The calcium hydroxide peaks were strongly distinguished at the 2-Theta: $18.07,28.725,34.132,47.176$, and 50.873 . In addition, the calcium silicate hydrates, CSH (I) and (II) was shown as the main hydration products, Figure 7. On the other hands, it was known that the main hydration products of hardened OPC-MK10 were nearly amorphous, besides the microcrystallinity of calcium silicate hydrates (CSH), calcium hydroxide $(\mathrm{CH})$, and calcium aluminosilicate hydrates (CASH). However, it could be

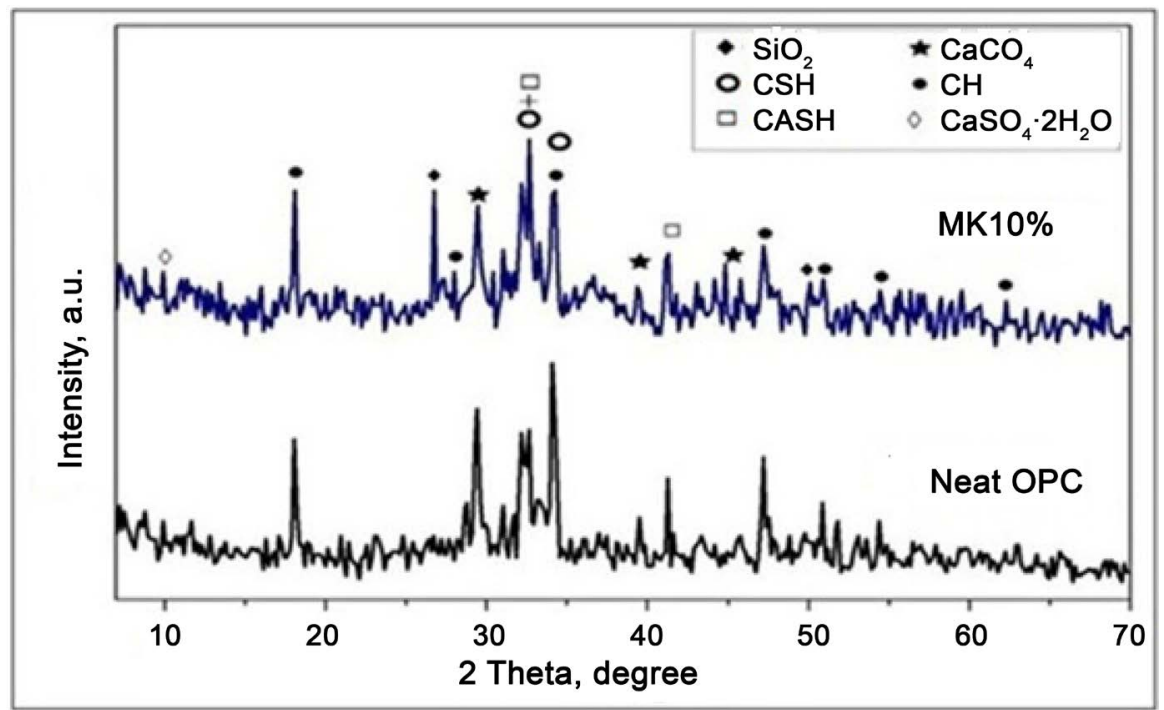

Figure 7. The XRD analysis of the hardened neat OPC and the OPC-MK10 after 28 days of hydration. 
Table 11. The XRD analysis data of the hardened cement pastes made of the neat OPC and the OPC containing $10 \% \mathrm{MK}$ after 28 days of hydration.

\begin{tabular}{|c|c|c|c|c|c|}
\hline Caption & 2-Theta ${ }^{\circ}$ & d-value, $\mathrm{A}$ & Intensity & Intensity\% & Phase \\
\hline$d=7.56313$ & 11.691 & 7.56313 & 9.72 & 20.5 & $\mathrm{CaSO}_{4} \cdot 2 \mathrm{H}_{2} \mathrm{O}$ \\
\hline $\mathrm{d}=4.89984$ & 18.09 & 4.89984 & 29.1 & 61.5 & $\mathrm{CH}$ \\
\hline $\mathrm{d}=4.25051$ & 20.882 & 4.25051 & 6.54 & 13.8 & Q \\
\hline $\mathrm{d}=3.33405$ & 26.717 & 3.33405 & 22.9 & 48.3 & Q \\
\hline $\mathrm{d}=3.03022$ & 29.453 & 3.03022 & 33.5 & 70.8 & $\mathrm{CaCO}_{3}$ \\
\hline $\mathrm{d}=2.87200$ & 31.116 & 2.872 & 13 & 27.5 & $\mathrm{CSH}-\mathrm{CASH}$ \\
\hline $\mathrm{d}=2.77859$ & 32.19 & 2.77859 & 35.1 & 74.2 & $\mathrm{CSH}$ \\
\hline $\mathrm{d}=2.73983$ & 32.658 & 2.73983 & 34.7 & 73.4 & $\mathrm{CSH}$ \\
\hline$d=2.68747$ & 33.312 & 2.68747 & 19.3 & 40.7 & \\
\hline$d=2.62222$ & 34.166 & 2.62222 & 47.3 & 100 & $\mathrm{CH}$ \\
\hline $\mathrm{d}=2.28112$ & 39.472 & 2.28112 & 11 & 23.2 & $\mathrm{CaCO}_{3}$ \\
\hline $\mathrm{d}=2.18983$ & 41.19 & 2.18983 & 19.1 & 40.4 & CASH \\
\hline $\mathrm{d}=2.12981$ & 42.406 & 2.12981 & 6.03 & 12.7 & \\
\hline $\mathrm{d}=1.92377$ & 47.208 & 1.92377 & 21.7 & 45.8 & $\mathrm{CH}$ \\
\hline $\mathrm{d}=1.79388$ & 50.86 & 1.79388 & 13.9 & 29.3 & $\mathrm{CH}$ \\
\hline $\mathrm{d}=1.76440$ & 51.772 & 1.7644 & 8.27 & 17.5 & \\
\hline $\mathrm{d}=1.68547$ & 54.39 & 1.68547 & 10.4 & 22 & $\mathrm{CH}$ \\
\hline$d=1.62992$ & 56.407 & 1.62992 & 8.82 & 18.6 & \\
\hline
\end{tabular}

remarked that, the intensity of calcium hydroxide $(\mathrm{CH})$ peaks of OPC-MK10 was lower than in case of neat OPC due to its consumption after the reaction with $\mathrm{MK}$, while the peak intensity of the hydration products of calcium silicate hydrates (CSH) and calcium aluminates silicate hydrates (CASH) of OPC-MK10 were higher than in case of neat OPC, Figure 7. Table 11 illustrates the main XR Diffraction lines, the 2-Theta degrees and the d-spacing of the detected mineral phases.

\subsection{Scan Electron Microscopy Pictures for the Hardened Neat and OPC-MK10 after 28 Day of Hydration}

The SEM micrographs of the neat OPC paste hydrated for 28 days showed the formation of crumpled fibrous particles of tobermorite-like CSH phases was indicated as the dominant hydration products in the hardened neat OPC, Figure 8. The hexagonal calcium aluminates hydrates and the hexagonal calcium hydroxide (portlandite) were shown to be deposited in the originally water-filled spaces, in addition to unhydrated cement grains, Figure 8. Additionally, the SEM micrographs of the hardened OPC-MK10 after 28 days of hydration indicated the formation of crumpled fibrous particles with dense structure of tobermorite-like CSH phases as the dominant hydration products among the other 


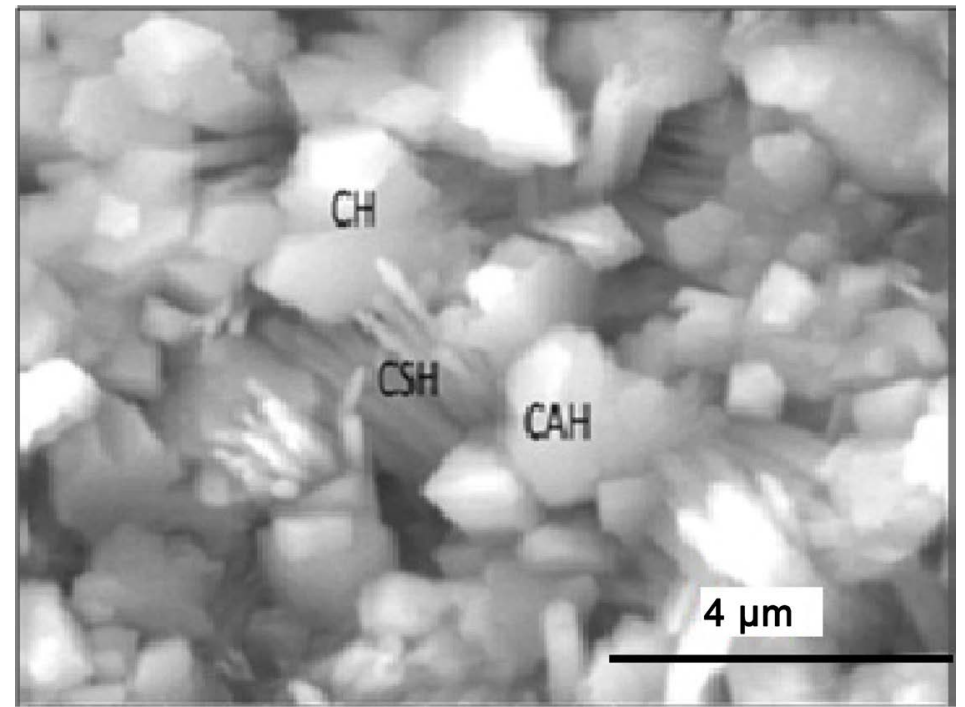

Figure 8. The SEM micrograph for the hardened neat OPC after 28 days of hydration.

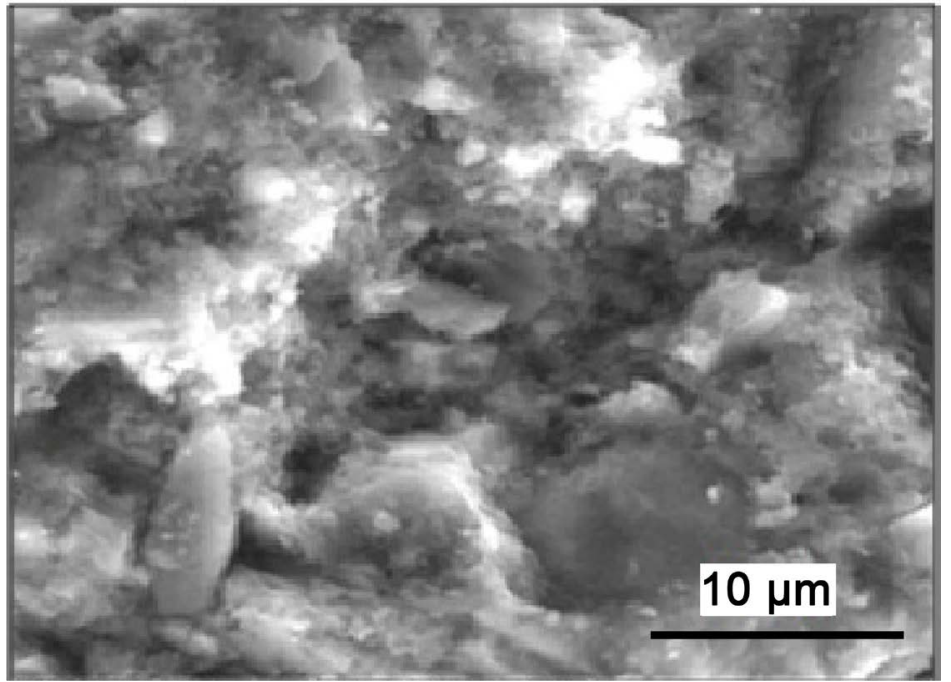

Figure 9. The SEM micrograph for the hardened OPC-MK10\% after 28 days.

hydrated phases deposited in the originally water-filled spaces in addition to the presence of unhydrated cement and metakaolin grains, Figure 9. It could be strongly remarked that the presence of calcium hydroxide $(\mathrm{CH})$ with its distinguished hexagonal crystal structure as well as the pores that were appeared clearly in the neat OPC matrix were highly disappeared in case of OPC-MK10 micrographs, Figure 8 and Figure 9.

\section{Conclusions}

- All the hardened blended pastes made of ordinary Portland cement with different amounts of metakaolin i.e. 5, 10\%, 15\% showed improvement in their compressive strength and hydration kinetics than that of the neat OPC.

- Blended pastes made of $90 \%$ OPC $+10 \% \mathrm{MK}$ showed the highest compressive strength and the lowest produced free lime contents values at all hydra- 
tion ages as compared to other pastes containing 5\% and 15\% MK.

- DSC thermograms and XRD diffractograms obtained for the hardened pastes OPC-MK10 at ages of hydration 14 and 28 days indicated the formation of calcium silicate hydrates (mainly as CSH. I\& II), calcium sulphoaluminate hydrates (ettringite and monosulphate hydrates), calcium aluminates hydrates, $\mathrm{CH}$ and $\mathrm{CaCO}_{3}$.

- Scanning electron microscopy micrographs indicated the formation of denser microstructure for the hardened OPC-MK10 pastes as compared to neat OPC pastes after 28 days of hydration.

\section{References}

[1] Alujas, A., Fernández, R., Quintana, R., Scrivener, K.L. and Martirena, F. (2015) Pozzolanic Reactivity of Low Grade Kaolinitic Clays: Influence of Calcination Temperature and Impact of Calcination Products on OPC Hydration. Applied Clay Science, 108, 94-101. https://doi.org/10.1016/j.clay.2015.01.028

[2] Rashad, A.M. (2013) Metakaolin as Cementitious Material: History, Scours, Production and Composition-A Comprehensive Overview. Construction and Building Materials, 41, 303-318. https://doi.org/10.1016/j.conbuildmat.2012.12.001

[3] Shi, Z.G., Lothenbach, B., Geiker, M.R., Kaufman, J., Leemann, A., Ferreiro, S. and Skibsted, J. (2016) Experimental Studies and Thermodynamic Modeling of the Carbonation of Portland Cement, Metakaolin and Limestone Mortars. Cement and Concrete Research, 88, 60-72. https://doi.org/10.1016/j.cemconres.2016.06.006

[4] Ludwig, H.M. and Zhang, W. (2015) Research Review of Cement Clinker Chemistry. Cement and Concrete Research, 78, 24-37. https://doi.org/10.1016/j.cemconres.2015.05.018

[5] Lollini, F., Redaelli, E. and Bertolini, L. (2016) A Study on the Applicability of the Efficiency Factor of Supplementary Cementitious Materials to Durability Properties. Construction and Building Materials, 120, 284-292.

https://doi.org/10.1016/j.conbuildmat.2016.05.031

[6] Alessandra, M., Alberto, B., Chiara, G., Tiziano, B. and Francesca, T. (2016) Metakaolin and Fly Ash Alkali-Activated Mortars Compared with Cementitious Mortars at the Same Strength Class. Cement and Concrete Research, 88, 198-210. https://doi.org/10.1016/j.cemconres.2016.07.004

[7] Walker, R. and Pavia, S. (2011) Physical Properties and Reactivity of Pozzolans and Their Iinfluence on the Properties of Lime-Pozzolan Pastes. Materials and Structures, 44, 1139-1150. https://doi.org/10.1617/s11527-010-9689-2

[8] Bu, Y.H., Du, J.P., Guo, S.L., Liu, H.J. and Huang, C.X. (2016) Properties of Oil Well Cement With High Dosage of Metakaolin. Construction and Building Materials, 112, 39-48. https://doi.org/10.1016/j.conbuildmat.2016.02.173

[9] Rashad, A.M. (2016) Cementitious Materials and Agricultural Wastes as Natural Fine Aggregate Replacement in Conventional Mortar and Concrete. Journal of Building Engineering, 5, 119-141. https://doi.org/10.1016/j.jobe.2015.11.011

[10] Shafiq, N., Nuruddin, M.F., Khan, S.U. and Ayub, T. (2015) Calcined Kaolin as Cement Replacing Material and Its Use in High Strength Concrete. Construction and Building Materials, 81, 313-323.

https://doi.org/10.1016/j.conbuildmat.2015.02.050

[11] Gameiroa, A., Santos Silva, A., Veigab, R. and Velosac, A. (2012) Hydration Prod- 
ucts of Lime-Metakaolin Pastes at Ambient Temperature with Ageing. Thermochimica Acta, 535, 36-40. https://doi.org/10.1016/j.tca.2012.02.013

[12] Frank, H. (1977) Clay. Watson-Guptill Publications, New York.

[13] Bulent, C., Çagrı, Ç., Ahmet, T., Beytullah, A. and Erdal, E. (2013) Covalent Grafting of Pyridine-2-Methanol into Kaolinite Layers. Journal of Molecular Structure, 1032, 12-22. https://doi.org/10.1016/j.molstruc.2012.08.004

[14] Murray, H.H. (2000) Traditional and New Applications for Kaolin, Smectite, and Palygorskite: A General Overview. Applied Clay Science, 17, 207-221. https://doi.org/10.1016/S0169-1317(00)00016-8

[15] Prasad, M.S., Reid, K.J. and Murray, H.H. (1991) Kaolin: Processing, Properties and Applications. Applied Clay Science, 6, 87-119. https://doi.org/10.1016/0169-1317(91)90001-P

[16] Murray, H.H. (1991) Overview: Clay Mineral Applications. Applied Clay Science, 5, 379-395. https://doi.org/10.1016/0169-1317(91)90014-Z

[17] Nkoumbou, C., Njoya, A., Njoya, D., Grosbois, C., Njopwouo, D. and Yvon, J. (2009) Kaolin from Mayouom (Western Cameroon): Industrial Suitability Evaluation. Applied Clay Science, 43, 118-124. https://doi.org/10.1016/j.clay.2008.07.019

[18] Sanz, J., Madani, A., Serratosa, J.M., Moya, J.S. and Aza, S. (1988) Aluminum-27 and Silicon-29 Magic-Angle Spinning Nuclear Magnetic Resonance Study of the Kaolinite-Mullite Transformation. Communications of the American Ceramic Society, C71, 418-421. https://doi.org/10.1111/j.1151-2916.1988.tb07513.x

[19] Kristof, E., Juhasz, Az. and Vassanyi, I. (1993) The Effect of Mechanical Treatment on the Crystal Structure and Thermal Behavior of Kaolinite. Clays and Clay Minerals, 41, 608-612. https://doi.org/10.1346/CCMN.1993.0410511

[20] Moya, J.S. (1998) Últimos Avances Sobre el Tratamiento Térmico del Caolín: Formación O No de Puzolanas Artificiales. In: Memorias Congreso Puzolanas Naturales, Cenizas Volantes Y Similares en la Construcción, Cemento y Hormigón, 71-75.

[21] Changling, H., Makovicky, E. and Bjame, O. (1994) Thermal Stability and Pozzolanic Activity of Calcined Kaolin. Applied Clay Society, 9, 165-187. https://doi.org/10.1016/0169-1317(94)90018-3

[22] Piga, L. (1995) Thermogravimetry of a Kaolinite-Alunite Ore. Thermochimica Acta, 265, 177-187. https://doi.org/10.1016/0040-6031(95)02429-6

[23] Dubois, J., Murat, M., Amroune, A., Carbonneau, X. and Gardon, R. (1995) HighTemperature Transformation in Kaolinite: The Role of the Crystallinity and of the Firing Atmosphere. Applied Clay Society, 10, 187-198. https://doi.org/10.1016/0169-1317(95)00030-8

[24] Balek, V. and Murat, M. (1996) The Emanation Thermal Analysis of Kaolinite Clay Minerals. Thermochimica Acta, 282-283, 385-397. https://doi.org/10.1016/0040-6031(96)02886-9

[25] Wild, S., Khatb, J.M. and Jones, A. (1996) Relative Strength, Pozzolanic Activity and Cement Hydration in Superplasticised Metakaolin Concrete. Cement and Concrete Research, 26, 1537-1544. https://doi.org/10.1016/0008-8846(96)00148-2

[26] Sha, W. and Pereira, G.B. (2001) Differential Scanning Calorimetry Study of Ordinary Portland Cement Paste Containing Metakaolin and Theoretical Approach of Metakaolin Activity. Cement and Concrete Composition, 23, 455-461. https://doi.org/10.1016/S0958-9465(00)00090-1

[27] Shvarzman, A., Kovler, K., Grader, G.S. and Shlter, G.E. (2003) The Effect of Dehy- 
droxlation/Amorphiztion Degree on Pozzolanic Activity of Kaolinite. Cement and Concrete Research, 33, 405-416. https://doi.org/10.1016/S0008-8846(02)00975-4

[28] Newman, A.C. (1987) Chemistry of Clays and Clay Minerals. Longman Scientific \& Technical, London.

[29] Yip, C.K. and Deventer, S.J.S. (2003) Microanalysis of Calcium Silicate Hydrate Gel Formed within a Geopolymeric Binder. Journal of Materials Science, 38, 3851-3860. https://doi.org/10.1023/A:1025904905176

[30] Rocha, J. and Klinowski, J. (1990) Solid-State NMR Studies of the Structure and Reactivity of Metakaolinite. Angewandte Chemie International Edition, 29, 553-554. https://doi.org/10.1002/anie.199005531

[31] Grim, R.E. (1968) Clay Mineralogy. McGraw Hill Publishing, New York, 596.

[32] Mackenzie, R.C. (1970) Differential Thermal Analysis. Academic Press, London.

[33] Torres Sánchez, R.M., Basaldella, E.I. and Marco, J.F. (1999) The Effect of Thermal and Mechanical Treatments on Kaolinite: Characterization by XPS and IEP Measurements. Colloid Interface Science, 215, 339-344. https://doi.org/10.1006/jcis.1999.6241

[34] Castelein, O., Soulestin, B., Bonnet, J.P. and Blanchart, P. (2001) The Influence of Heating Rate on the Thermal Behavior and Mullite Formation from a Kaolin Raw Materials. Ceramic International, 27, 517-522. https://doi.org/10.1016/S0272-8842(00)00110-3

[35] Ibrahim, S.S., Abdel Rahman, M.K. and Selim, A.Q. (2011) Fine Disintegration of Egyptian Kaolin. Ore Dressing Journal, 12, 7-15.

[36] El-Diadamony, H., Amer, A.A., Sokkary, T. and El-Hoseny, S. (2016) Hydration and Characteristics of Metakaolin Pozzolanic Cement Pastes. Housing and Building National Research Center Journal. http://www.sciencedirect.com/science/article/pii/S1687404815000486

[37] Abo-El-Enein, S.A., Amin, M.S., El-Hosiny, F.I., Hanafi, S., El-Sokkary, T.M. and Hazem, M.M. (2014) Pozzolanic and Hydraulic Activity of Nano-Metakaolin. Housing and Building National Research Center Journal, 10, 64-72. https://doi.org/10.1016/j.hbrcj.2013.09.006

[38] Egyptian Specification (2010) The Standard Methods for the Chemical Analysis.

[39] Abo-El-Enein, S.A., Abbas, R. and El-Sayed, E. (2010) Properties and Durability of Metakaolin Blended Cements. Materiales de la Construccion, 60, 21-35. https://doi.org/10.3989/mc.2010.50509

[40] Han, J., Wang, K., Shi, J. and Wang, Y. (2014) Influence of Sodium Aluminate on Cement Hydration and Concrete Properties. Construction and Building Materials, 64, 342-349. https://doi.org/10.1016/j.conbuildmat.2014.04.089

[41] Pera, J., Rols, S., Chabannet, M. and Ambroise, J. (1998) Influence of the Cement Type on the Resistance of Concrete to an Agricultural Environment. In: Cohen, M., Mindess, S. and Skalny, J., Eds., Materials Science of Concrete; The Sidney Diamond Symposium, American Concrete Society, Farmington Hills, 419-430.

[42] Mlinarik, L. and Katalin, K. (2013) Impact of Metakaolin-A New Supplementary Material on the Hydration Mechanism of Cements. Acta Technical NapocensisCivil Engineering and Architecture, 56, 100-110.

[43] Frias, M. and Cabrera, J. (2001) The Influence of MK on the Reaction Kinetics in MK/Lime and MK-Blended Cement Systems at $20^{\circ} \mathrm{C}$. Cement and Concrete Research, 31, 519-527. https://doi.org/10.1016/S0008-8846(00)00465-8

[44] Nadeem, A., Memon, S.A. and Yiu, L.T. (2013) Mechanical Performance, Durabili- 
ty, Qualitative and Quantitative Analysis of Microstructure of Fly Ash and Metakaolin Mortar at Elevated Temperatures. Construction and Building Materials, 38, 338-347. https://doi.org/10.1016/j.conbuildmat.2012.08.042

[45] Nežerka, V., Slížková, Z., Tesárek, P., Plachý, T., Frankeová, D. and Petráňová, V. (2014) Comprehensive Study on Mechanical Properties of Lime-Based Pastes with Additions of Metakaolin and Brick Dust. Cement and Concrete Composites, 64, 17-29. https://doi.org/10.1016/j.cemconres.2014.06.006

[46] El-Gamal, S.M.A., Amin, M.S. and Ramadan, M. (2015) Hydration Characteristics and Compressive Strength of Hardened Cement Pastes Containing Nano-Metakaolin. Housing \& Building National Research Center (HBRC) Journal, 13, 114-121. 